\title{
Speculation: The Islamic Perspective; A Study on Al-Maisir (Gambling)
}

\author{
Hussin Bin Salamon \\ Faculty of Islamic Civilization, University Technology of Malaysia (UTM), 81310 Johor Bahru, Malaysia
}

Mansoureh Ebrahimi

Faculty of Islamic Civilization, University Technology of Malaysia (UTM), 81310 Johor Bahru, Malaysia

Email: suriebrahimi@gmail.com

Kamaruzaman Yusoff

Faculty of Islamic Civilization, University Technology of Malaysia (UTM), 81310 Johor Bahru, Malaysia

\section{Doi:10.5901/mjss.2015.v6n1s1p371}

\section{Abstract}

Speculation is ineluctable. Every business transaction, including ancient barter systems, involves, to a certain extent, some aspect of speculative judgement due to human nature's striving for a better future. This article discusses the Islamic perspective on speculation with a special focus on the stock exchange. In particular, Al-Maisir (gambling) is examined in order to clarify the matter for readers interested in the subject.

Keywords: Speculation; Stock Exchange; Al-Maisir (Gambling);

\section{Introduction}

The generally broad understanding of the word 'speculation' refers to anything dealing with probabilities and uncertainties concerning the future. Such uncertainty is dealt with through the intellect using faculties of sight, reason and contemplation. Islam holds that humans are the only creatures on earth who possess and are empowered with the ability to think, ponder, contemplate and make decisions and further teaches that the existence of speculative judgement originated with the first humans.

Adam, as the first created human being, was honoured with intellect and emotion. The endowment of these abilities gave him a status higher than angels (Qur'ān 2:34-5) and were essential qualities required to steer him through life in a world that demanded self-initiated, pro-active independence to accomplish his duty as Allah's vicegerent on earth (Qur'ān 2:30). Hence, through 'aql (intellect) and physical capability, humans may explore and utilise everything on earth for their benefit (Qur'ān 14:32-3; 16:12-4; 22:65; 45:13 and others). In other words, each of these ni'mah (bounties) was purposely provided by Allah to grant mankind abilities to undertake amānah (responsibility) in this world. Hence, no one can deny his/her personal actions which will be accounted for on the Day of Judgement.

Nonetheless, although human beings possess intellect and the faculty of choice, they always remain in need guidance from our Creator. Our faculty of choice is influenced by two substantial adversaries, Satan and desire (Qur'ān 2:168; 2:208; 4:92; 7:22; 12:53; 79:40; 91:8). Adam and Eve's descent to this world was caused by the Evil Spirit. The situation they faced when choosing whether or not to eat required a speculative process since it involved faculties of thought and contemplation. Their speculative judgement in choosing what was best proved wrong.

Humans honoured with 'aql (intellect) must speculate in life. However, the correctness of decisions made varies based on at least two things; their status as well as their analytical competency. When referring to status, all prophets, as believed by Muslims, are classed differently from ordinary human beings since they were ma'șūm (infallible) and fațanah (clever). As prophets, the guidance of God was always with them; in which case their decisions were supreme when compared to ordinary humans. However, their 'ordinary speculative judgement in a few cases proved only as good as the next person's. One such instance was shown by Muhmmad's decision to defend Madinah from within the city (Battle of Badar), which was discussed and rejected when one of his companions decided to defend Madinnah from without. Human analytical competency for consequently drawing correct conclusions depends on various factors such as brilliancy, talent, skill and available information as well as his/her willingness to take the risk of being wrong. One important factor for 
successful decision making in the Islamic view is help from God. Muslims believe they may make plans and descisions but that God also makes plans and decisions and He is the best planner and decision maker (Qur'ān, 8:30).

The discussion thus far demonstrates teachings of Islam that regard decisions through speculative judgement as something that is naturally done by everyone. This is because every decision made may be in expectation of a good outcome yet there is no guarantee of correctness. Hence, the speculative nature of decision making exists, especially as life is full of uncertainty.

\section{Speculation in the Stock Market; the Islamic Perspective}

The existence of speculative judgement is important due to its intimate relation with the faculty of intellect. As far as speculative judgement in economics is concerned, it takes place in almost every business transaction (Aubrey 1896). Even with a wider application of the word, to hold wealth in whatever form is impossible without having to speculate on future changes in its value against other assets. Hence, in this respect, money is held on a speculative basis (Dow and Earl 1982). A famous speculator once dared to say "the spirit of speculation is born with men" (Teweles, R.T. et al. 1965). Hence the connection between speculative judgement and human life is inevitable and people unavoidably exercise it to the best of their ability. From this perspective, speculation, in its basic and most literal understanding and application, is allowed under the Islamic framework (Khan 1988).

However a question emerges as to the extent of its permissibility. Are all kinds of economic judgements that are speculative in nature acceptable in the Islamic economic system or should some be rejected? This query particularly concerns speculative business transactions that take place in the stock market, the main subject of the present study. There exist elements of al-maisir (gambling), al-gharār (uncertainty), malpractice, unethical activities and 'unearned income' in speculative stock market transactions; matters that are patently undeniable. But here the discussion focuses on the close relation of al-maisir to speculative activity in the stock market with hopes to shed clarifying answers to the question. Although some of these elements are obviously seen in speculative stock market transactions, others are not. Hence, a detailed discussion on the presence of every speculative stock market element follows below.

Some elements of speculative stock market transactions are similar to gambling. In some types of gambling such elements are sometimes present and in others, only a few of these elements arise. Some are easily recognised as gambling while others are indistinguishable from a business transaction. However, before giving a detailed account of these elements, the writer will define gambling and present a concise background of its practice.

\section{The Definition of Al-Maisir (Gambling)}

Gambling and other terms such as gaming and 'games-of-chance' derive from the Anglo-Saxon 'gamen' and 'gamon' which mean sport or play. The general use of the word gamble denotes any decision executed in any transaction or pursuit involving risk and uncertainty. Hence, gambling is to play a game of chance for money; or to take a risk for some advantage; or a risky venture. Risk and uncertainty are faced in gambling since the outcome of the decision taken is unknown even though a good outcome is always expected. Therefore, it is said that politics, in fact, are 'a big gamble' since judgements passed in this area are always uncertain and risky. The use of the word usually, however, refers more specifically to economic activity which is very concerned with the aspect of gain, loss, risk and uncertainty relating to the 'game of chance'. Economically, therefore, to gamble is to "play 'games-of-chance' for money especially for unduly high stakes; or to stake money (especially to an extravagant amount) on some fortuitous event" (The Oxford English Dictionary, 1989).

However, this definition is too narrow because the words 'to play games' does not accommodate all types of gambling. There are business transactions which are certainly gambling in nature but could not be included under the definition of 'games'. Furthermore, there are many kinds of gambling that are not based purely on chance such as betting on horse races, boxing or other sporting events, even though outcomes are unpredictable. In addition, the words 'for money' in the above definition do not suit all kinds of modern gambling. Although, monetary gain remains the main objective of much gambling, it is not considered the sole purpose of a 'game of chance'. There are various alternative prizes to be won including political power, leadership and, to a certain extent, women. As mentioned by Cohen and Hansel in their writing, Scythians staked not only their teeth, eyebrows, wives, families and freedom, but also risked their lives on a single throw of the dice (Cohen, 1956).

Green, in his work, Betting and Gambling, suggested a definition he claimed was more comprehensive. He defined 'to gamble' as "an agreement between two parties whereby the transfer of something of value from one to the other is 
made dependent on an uncertain event, in such a way that the gain of one party is balanced by the loss of another," (Green, 1930). Accordingly, this definition fits all types of gambling such as playing 'games-of-chance' or betting on horse racing and other sporting events between clients and bookmakers or between individuals; including all kinds of sweepstakes, lotteries and similar enterprises (Gambling, 1931). Furthermore, the definition given even includes certain business transactions (Green, 1930).

The above definition claims a comprehensive statue yet it still excludes a few important aspects such as risk, hope of gain and the element of chance. The New Encyclopædia Britannica (1977) offers a closer description of the truth by stating that:

"... gambling is the betting or staking of something of value, with consciousness of risk and hope of gain, on the outcome of a game, a contest, or an uncertain event, the result of which may be determined by chance or accident or has an unexpected result by reason of the bettor's miscalculation."

This definition excludes sophisticated business transactions that, nevertheless. embody elements of gambling such as the stock market and foreign exchange transactions. Here, at least two significant gambling elements were excluded from the definition offered: the element of economic fundamentals and economic manipulation. Hence, the present writers suggest a renewed definition for gambling as follows:

The betting of something of value with unnecessary risk with the hope of gain based on elements of chance and uncertain events that may involve, to a certain extent, economic manipulation and, on occasion, loss of the contextual elements of economic reality.

\section{Concise Background of Gambling}

Gambling or 'games-of-chance' are believed to be as old as the dawn of civilisation and have been used to facilitate decision making in law, military operations, ceremonies, liturgy and economics (Morgenstern, 1973). According to Paton, these matters were possibly decided by various methods of divination in primitive times to allow people to decisively discern their future (Paton, 1913). Hence, the primary objective was, initially, decision-making. However, to add some sporting zest, gambling became 'secularised' by risking some stake or possession on the turn of chance (Paton, 1913).

In ancient cultures, gambling had significant religious connotations attached to myth and ritual. As such, it was not regarded as 'gambling' in the sense of the word's contemporary use. The casting of lots is said to have been purposely utilized to end disputes, to divide or distribute property or divine God's Will (The New Encyclopædia Britannica, 1977). However, insufficient studies have been made on the cultural and religious significance of gambling as claimed by diffusionists.

Nevertheless, archaeological findings the world over strongly suggest that the origin of religious gambling, as claimed by diffusionists, is irrefutable. This is chiefly because painted pebbles, dice, board games, astragali and other such artefacts-all gambling implements-date to as early as 3500 BC (Hiltebeitel, 1987). Since a large number of astragali were discovered in many pre-historic site excavations, it has been suggested that people tossed these bones in 'games-of-chance' even as long as 40,000 years ago (Hiltebeitel, 1987). While some of these ancient 'games-of-chance' continue in use to this day in regions of their archaeological digs, numerous modern implements and methods have since been created to 'entertain' the human urge to gamble.

\section{Elements of al-Maisir in Speculative Stock Market Transactions}

From ancient times, 'games-of-chance' were widely used to facilitate solutions for various life events. However, as time progressed gambling was secularised by staking money or valuable possessions for the purpose of obtaining some form of material gain from other people. In today's world, when the words 'game-of-chance' are used, they refer solely to this 'secularised' aspect with the more familiar words of 'gambling' or 'betting'. The following items are a few elements embodied in speculative stock market transactions simultaneously held in common with outright gambling.

\subsection{The Elements of Hope and Luck}

Hope and luck inescapably arise when exercising speculative judgement in any business transaction and Islam frankly views both as matters that do not contradict its teachings. Nevertheless, Islam holds a very clear position in that hope and luck must be associated with tireless work before a decision is exercised. The metaphysical estate of concern here is that 
of al-tawakkul (being fully surrendered to God), which Islam distinctly prescribes as follows, "... then, when thou hast taken a decision, put thy trust in Alla, for Allah loves those who put their trust in Him" (Qur'ān 3:159; 4:81; 11:123; 33:3). This verse clearly states that God not only commands humans to be immersed in al-tawakkul but that He also loves those who surrender to Him after the work of surrender is performed tirelessly. Hope, therefore, is certainly present but it is directed towards God with Whom all luck (benefit) originates.

Hence, Islam does not accord with the idea of al-tawakkul minus the onerous detail of real work as understood by some Muslims. The implication is that Islam rejects 'blind tawakkul' and the more correct concept used in such cases is al'tawākul (laziness) (Mu'jam al-Wāsiț, 1973). Those who depend purely on hope and luck without responsibly undertaking hard work are considered by God as people without faith. This is because a man's surrender without doing work is the same as abandoning hope in God. This assertion is made plain in the following verse:

"O my sons, go ye and enquire about Joseph and his brother and never give up hope of Allāh's Soothing Mercy, truly no one despairs of Allāh's Soothing Mercy except those who have no faith." (Qur'ān, 12:87)

More specifically, the element of luck must also be viewed from the Islamic perspective. Luck is associated with the idea of al-qadar (a due proportion) in Islam. From the conventional economic point of view, luck is something purely accidental or 'by chance', while Islam teaches that luck is pre-destined by God as a manifestation of His unlimited acknowledgment (Samuelson, 1958; Rix, 1965). Hence, everything that happens to each individual is already stated in lauh al-mahfüz (the protected tablet) (Qur'ān 7:154; 15:9; 85:22) and the idea of luck in Islamic economics replaces the conventional understanding with a more correct exposition.

The discussion so far has summarized the concepts of al-tawakkul and al-qadar in Islam, implying that the acceptability of hope and luck therefore depends on these illustrations. Moreover, as the implementation of these elements must accord with the teaching and spirit of Islam, their more correct involvement in speculative judgement, as elements in any business venture (including the stock exchange), is fundamentally acceptable. This position remains valid as long as the understanding and spirit of Islam regarding both are correctly appreciated (Saeed, M. et al., 2001); especially since the better defined perspective ensures that business transactions do not include more serious elements prohibited by Islam, namely, betting, or more precisely, gambling.

\subsection{The Element of Betting}

An acceptable speculative transaction must be free from betting, an element of gambling. In Islam, the validity of any business transaction requires that it is free from gambling. Even so, there are businesses and welfare organisations in today's world that hide this 'betting' component behind all kinds of good names. But it matters not what name is used or what the purpose is intended, as these do not nullify prohibitions in business as prescribed by the Qur'ān. This includes many forms of lottery and toto syndicates run by governments and private organisations to collect money for charity and economic gain. This business of 'betting for charity' is undertaken by many countries, including Muslim nations, although some of the latter have forbidden it. But regardless of who runs such an enterprise, the position of Islam on its prohibition remains valid and will continue as such. This prohibition is based on the gist of the transaction and not on the name or purpose of the managing organisation or government. As long as it involves the element of betting on gain without work, Islam forbids it.

The prohibition on gambling is clearly stated in the Qur'ān and stands immutable (Qur'ān 2:219; 5:90-1). This proscription is not only limited to gambling for the acquisition of money but it is also applicable to 'games-of-chance' or gambling for the purpose of entertainment and recreation (Qaraḍāwī, 1985). If one's involvement in a game-of-chance even for relaxation is forbidden, this same prohibition becomes more easily grasped in cases of gambling to attain profit at the expense of others. Hence, the application of this position extends, therefore, also to the process of passing similar judgements on speculative stock market transactions.

Thus, when perusing speculative transactions in the stock market, the clement of 'betting' is clearly embodied in such transactions in their present form. Since speculators inject surplus income in the market based on imaginative factors such as rumours and price trends, the element of forbidden betting is palpably present. Authentic investors buy shares based on analytical assessment of a company's economic fundamentals, but speculators buy shares based on market sentiment while, at the same time, detaching themselves from the economic realities of the company's position in the community. Hence the betting element reigns supreme as clearly stated by Bach:

"The market price of stocks is determined by thousands of other people who are all guessing. Many of them are in the 
market as speculators, looking for a quick dollar on the price rise rather than for a long-pull investment . . . so you are betting on what other people will bet on and they in turn are betting on what you and others will bet on." (Bach, 1974)

This betting of surplus money in speculative stock market transactions manifested in the crash of the New York Stock Exchange (NYSE) in 1929. Millions of people were involved in these transactions, especially in margin trading. During its peak period, it was noised abroad that no one will lose as the 'bull' market continues. As testified by Fred Fantasy who described the NYSE, "This market has been like a money machine. I have now taken six straight profits on the short side," (Teweles, R.T. et al., 1965). However, as correctly pointed out by Teweles, "In any game in which probabilities are involved, the longer you play the more certain it becomes that a series of losses will occur," (Teweles, R.T. et al., 1965). This became manifest in the crash when small unprofessional speculators and investors became victims of large speculators as revealed by the studies of Rockwell and Blair after the crash. The reality of gambling in securities was further acknowledged by Warren when he mentioned that investors always become victims of speculators through 'bulls' and 'bears' if they do not fully understand market mechanisms (Warren, 1906).

A point of note is that the game of speculative judgement in the NYSE crash not only involved professional speculators or investors turned speculators, but the euphoria preceding the crash seems to overpower everybody so that brokers were also attracted and consequently associated themselves in the mania (Lechner, 1980). Hence not only were real speculators betting money in the market, but brokers also wagered for instant profits from the 'bull' market. Thus, the heat of this speculative mania-where large manipulative players won handsomely-attracted everyone's indulgence. This 'gambling' on speculative stock market transactions was so attractive that some participants were actually unaware of their mindless involvement. This was admitted by Lechner who bet US $\$ 3,300$ in 100 Bally shares on the NYSE. He said, "I told my broker to sell it if it fell to $\$ 30$. I did not know what I was doing, other than I was gambling on gambling. And since I never walk into a Casino with more than $\$ 100$ in my pocket, I figured that play in a casino stock was worth only a \$300 loss," (Lechner, 1980).

\subsection{The Element of Taking the Advantage}

Being taken advantage of by professional speculators in the market is the ever so present reality. Such professionals clearly do not conform to Islamic economic doctrine as Islam disallows deceptive opportunism and the taking of another person's property by dissembled maneuvering. The Qur'ān makes this patently clear: "O ye who believe, eat not up your property among yourselves in vanities but let there be amongst you traffic and trade by mutual good-will..." (Qur'ān 4:29). Hence, it is understood that to take advantage of another person is denounced by Islam, which is, specifically, the taking advantage of the weakness of a speculator and investor, and taking advantage of real or artificially devised inefficiencies in the market.

This taking advantage is rampantly endemic in today's stock exchanges at the hands of professional speculators who manage handsome profits at the expense of small, new and unprofessionally informed speculators. The sad and prevailing fact is that these greedy professionals knowingly, wantonly and selfishly victimize (Teweles, R.T. et al., 1965) all those in the market who lack inside knowledge or basic forecasting ability; those who merely act on the basis of rumours and impulse (Chapra, 1985).

The situation where one party (professional speculators) consistently wins the game at the expense of unprofessional speculators leads us to the element of one party gains at the loss of other parties (Clarke and Dempsey, 2001), which is exactly what took place in the in the 1929 NYSE crash. In the words of Lechner:

"... the stock market tail spinned and crashed...individuals fled the market with what little was left, vowing (as he had before) never to return ... . [but] as long as the game might still make someone rich, it will have its participants." (Lechner, 1980)

In addition, this professional manipulation causes prevailing inefficiencies in the market that permit even further plunder. This, in turn leads to unnecessary (and unnatural) disturbances in price fluctuations in an otherwise free market (Rix, 1965). Such circumstances lead to price and market instability as pointed out by Aliber whose survey results indicated that when speculative transactions occur they frequently causes amplification rather than dampening in the range in spot price movements (Aliber, 1964). This disturbance of a free market contradicts the economic teaching of Islam by qualifying as price manipulation on the part of the speculator (Qaraḍāwī, 1985). Accordingly, price interference in a free market is forbidden so as to safeguard the public interest rather than the interests of a small group of speculators (Qaraḍāwī, 1985). Hence, we may safely deduce that the taking of advantage in any business activity does not conform 
with Islamic economic doctrine or business ethics.

\subsection{The Element of Corporate Fundamentals}

The element of a company's fundamentals is an important aspect for investors to know prior to making an investment. Such disclosures are crucially vital for every investor who stakes surplus money in endeavors that are economically sound and reliable rather than imaginatively unrealistic. Such evaluations are based on current assets, prior performance, viable future planning and all elements related to the company. Thus, when viewed from an economic perspective, to invest based on -in the words of Kindleberger- "lost contact with reality" will bring 'de trop' consequences to the economy (Kindleberger, 1977).

Taking the cited precautionary measures assures investors that the economic stability of a company as well as a country continues to flourish. Hence, investing money in business ventures by properly analysing their strengths and weaknesses is simply the doing of good business. Investments based on fundamental aspects of a company are greatly affected by changes in economic situations, especially those that occur due to untruthful information or rumour. Hence, there would be no need to worry about the investment made since the investment was soundly based on fundamentals that 'exist'. What the present writer means is that fundamental assets are real rather than imagined (speculated). Hence, if the company were to close, the investor may expect to receive some return.

But this is not the case when speculators invest surplus money blindly and the injection of their money is based on expectations of profit that are highly imaginative in nature; especially should they confront changing economic situations, in which circumstances the value of their shares could be easily and negatively affected. This is because the basis of speculative investment does not really equate with true value. Hence, slight changes in economic conditions could be enough to cause huge fluctuations that gain momentum and spread. From something harmlessly small in nature, they become huge and, accordingly, are accepted as reasons for selling or buying shares by speculators. As imaginative investment is part of their life, they tend to be acutely responsive to any economic change, even small changes. Suicides occurred daily as billions of dollars were burnt in the 'game of speculative transaction' that took place in the US during the 1929 NYSE crash (Yass, 1970), and well as in the UK during the tragedy of the South Sea Bubble in 1720 (Warren, 1906).

In the tragedy of the South Sea Bubble, professional speculators caused the value of South Sea Company shares to rocket from $£ 100$ to $£ 1,000$ within a month. Suddenly (a few days after the peak), this unrealistic valuation began to fall and consequently returned almost to its real and original value (£175) (Warren, 1906). This historic tragedy indicates that the price of shares under speculative manipulation rarely represents the actual value of company shares being traded. Boughton and Wicker stated:

"... to be sure that market value depends primarily on what prospective stock purchasers think the stock is worth, there is no precise linkage between a company's current profits and the price of its stock in the open market..." (Boughton and Wicker, 1975).

In this tragedy, genuine investors, theoretically, should not have been affected by the decline in South Sea Company shares as they would have made their investment based on a real valuation of the company which was $£ 100$ per share. When the price began to rise, speculators stepped in to make the price per share soar. Although the speculative valuation of the company's shares had risen to $£ 1000$ within a month and then suddenly fell to only $£ 175$, original investors' shares remain at $£ 75$ above the price paid earlier in the month ( $£ 175-£ 100$ ). However billions of pounds ( $£ 1000-£ 175 \times$ no. of shares) of capital belonging to the society so tempted were wasted (stolen?) by the imaginative and speculative game of the South Sea Bubble.

Rationally, it is impossible for shares of a company to rise to more than ten times their original value within that short a time. Hence, its occurrence was simply due to an imaginary valuation detached from the real world. In the words of Kindleberger:

"The additional rise above the true capital will only be imaginary; one added to one, by any stretch of vulgar arithmetic will never make three and a half, consequently all fictitious value must be a loss to some person or other, first or last. The only way to prevent it to oneself must be to sell out betimes, and so, let the Devil take the hindmost" (Kindleberger, 1978).

Hence, while speculators suffered a great loss of surplus income, real investors should have been happily keeping their shares. The assumption on the part of the 'happy' position of investors is based on their determination not to be 
carried away by the very attractive game of speculative transaction. When they manage to hold to their principle of putting money to the purpose of real investment and not for the game of speculative transaction, they will succeed as real investors.

However, this may not occur for all investors in every financial crisis because of the enormous temptation presented by the game of speculation. As stated by Kindleberger, speculation usually develops in two stages (Kindleberger, 1978). First, those who possess surplus income invest in a company of their choice while holding tightly to the principles of investment. They invest their money after careful and knowledgeable analysis of the performance of the company as well as the market. When speculation starts to affect the market due to the efforts of speculators, especially large speculators, within a limited and controllable environment, real investors begin to re-think the principles of the investment they hold. As speculative prices rise further because of price manipulation, the second stage could occur at any moment. During this stage, irrationality overcomes rationality and the interest in business gains is overpowered by interest in capital gains. Now, by selling their principal (and principles), sober investors are transformed into greedy speculators. In which case, they could face the same consequences as unskilled speculators should an economic event or disaster strike the market. This is essentially due to their change from real investors to 'part time' speculators.

Two important studies were made subsequent to the 1929 NYSE crash. The Rockwell and Blair Studies proved that large and professional speculators consistently win at the expense of small and unprofessional speculators. The tragedies cited above clearly indicate that investment in business ventures must be based on business fundamentals and a realistic assay of the company's true worth. Hence, a proper analysis should be made and investments, based on purely imaginative and unrealistic elements, are to be avoided. The disastrous consequences of being purely imaginative when investing money is not only faced by individual investors but are also likely to cause a national economic disaster and possibly have negative effects on global economic achievements as well. Such is the everlasting testimony of the Great World Depression of the 1930s. Accordingly, to inject surplus money based purely on speculative and imaginative principles also contradicts Islamic economic teachings.

\section{Conclusion}

Regarding elements of gambling present in speculative stock market activity, Islam holds that speculation in various economic events is permissible. Nonetheless, such speculation is not to be integrated with elements denounced by Islam such as blind hope, pure luck and betting, or the taking advantage of those who remain ignorant of realistic economic fundamentals. Such forbidden matters are of grave concern as their implementation undermines and, thus also, jeopardizes participation in the permitted activities of rational speculation. Furthermore, when such elements are permitted to ferret their way into the decision making processes of business transactions in the stock exchange, they irredeemably lead to the situation described by Kindleberger as a 'loss of contact with economic reality'. If this economic scenario goes unchecked, it causes immense problems to local and even global economies as demonstrated by the Great Depression of the 1930s.

Our discussion has established that al-maisir (gambling) as speculative business transactions in the stock market clearly exist. In fact, as described by Lechner, the authority of the market is the 'promoter' of gains by creating new games that replace tried and truthful methods with false promises for participants. Such games continue under different names with different players and will always attract public contestants as long as someone or other strikes it rich at the expense of someone else. As the presence of these elements disturbs the correct and natural course of professional investors, they are therefore, and for other cited reasons, categorically renounced by Islam. Hence, the existence of these elements in speculative stock market transactions needs review, restriction and even abolishment so as to make the business of stock market trading practical and honest for every Muslim as well as just and equitable for all of mankind.

\section{References}

The Holy Qur'ān.

Anis, Ibrāhīm et al. (Eds.) (1973). Mu jjam al-Wāsiț. 2nd ed., vol. 2, Dar al-Fikr. Cairo.

Aliber, R. Z. (1964). "Speculation and Price Stability; Once Again." Journal of Political Economy, vol. 72.

Aubrey, W. H. S. (1896). Stock Exchange Investments: The Theory, Methods, Practice and Results. Simpkin, Marshall, Hamilton, Kent \& Co. Ltd., London.

Bach, G. L. (1974). Economics; An Introduction to Analysis and Policy. Prentice-Hall Inc., New Jersey.

Boughton, J. M. and E. R. Wicker (1975). The Principles of Monetary Economics. Richard D. Irwin Inc., Illinois.

Chapra, M. U. (1985). Towards a Just Monetary System. The Islamic Foundation, Leicester.

Clarke, R. and G. Dempsey (2001). "The Feasibility of Regulating Gambling on the Internet." Managerial and Decision Economics, 
22(1/3), 125-132.

Cohen, J. and M. Hansel (1956). Risk and Gambling: The Study of Subjective Probability. Longmans, Green and Co., London.

Dow, S. C. and P. E. Earl (1982). Money Matters; a Keynesian Approach to Monetary Economics. Martin Robertson, Oxford.

"Gambling" (1931). The Mathematical Gazette, 15(212), 347-358.

Green, P. (1930). Betting and Gambling. Student Christian Movement Press, London.

Hiltebeitel, Alf. (1987). "Gambling" in Encyclopedia of Religion. Mircea Eliade (Ed.). vol. 5, MacMillan Publishing Co., New York.

Khan, M.A. (1988)."Commodity Exchange and Stock Exchange in an Islamic Economy." Journal of Islamic Economics, vol. 1, no. 2, Kuliyyah of Economics, International Islamic University, Malaysia.

Kindleberger, C. P. (1978). Manias, Panics, and Crashes; A History of Financial Crises. Macmillan Press Ltd., London. (1977). The World in Depression, 1929-39. Allen Lane Penguin Books Ltd., London.

Lechner, A. (1980). Street Games: Inside Stories of the Wall Street Hustle. Harper \& Row, New York.

Morgenstern, O. (1973). "Game Theory" in Dictionary of the History of Ideas. Philip P. Wiener (Ed.). vol. 2, Charles Scriner's Sons, New York.

Paton, J. L. (1913). "Gambling" in Encyclopædia of Religion and Ethics. J. Hastings (Ed.). vol. 6, T \& T Clark, Edinburgh.

Qaraḍāwī, Y. (1985). Al-Halālwa al-Harāmfĩ al-Islām (The Lawful and the Prohibited in Islam). K. El-Helbawy, M. M. Siddiqui and S. Syukry (trans.). Shorouk International, London.

Rix, M. S. (1965). Stock Market Economics. Sir Isaac Pitman and Sons Ltd., London.

Saeed, M., Ahmed, Z. U. and S. M. Mukhtar (2001). "International Marketing Ethics from an Islamic Perspective: A Value-Maximization Approach." Journal of Business Ethics, 32(2), 127-142.

Samuelson, P. A. (1958). Economics; An Introductory Analysis. McGraw-Hill, New York.

Teweles, R. T., Harlow, C. V. and H. L. Stone (1965). The Commodity Futures Game. McGraw Hill, New York.

The New Encyclopædia Britannica (1977). "Gambling." in Micropædia, vol. 7. Encyclopædia Britannica Inc., Chicago.

The Oxford English Dictionary (1989). Under the entry "Speculation." (Ed. By Simpson, J.A and Welner, E.S.C., 2nd Ed.), Vol. 16, Oxford, Clarendon Press.

Warren, H. (1906). The Story of the Bank of England, 2nd ed. R. A. Everett \& Sons, London.

Yass, M. (1970). The Great Depression. Wayland Publishers, London. 